\title{
Biological activity of Bauhinia racemosa against Diabetes and Interlinked Disorders like Obesity and Hyperlipidemia
}

\author{
Vivek Kumar', Kalpana Rathore ${ }^{2}$, Parag Jain ${ }^{3^{*}}$ and Zabeer Ahmed ${ }^{4}$
}

\begin{abstract}
Background: Bauhinia racemosa Lam. (BR) has been used widely for the treatment of diabetes since ancient times. Along with its medicinal importance; the tree having great traditional value in India. The protocol was performed using Wistar rats to determine the effect of petroleum ether extract of BR leaves on blood glucose level, adipose tissue and lipid profile. The study was further evaluted to determine insulin level, glucose tolerance, food and water intake of the animals.

Methods: Wistar rats of both sexes were selected for the study. Diabetes was induced by intraperitoneal injection of streptozotocin (STZ) $45 \mathrm{mg} / \mathrm{kg}$. Animals were divided into five groups namely control group, diabetic group, reference group (glibenclamide) and two test groups BR-1 (250 mg/kg extract) and BR-2 (500 mg/kg) each group containing 6 animals. Daily dosing was performed for 28 days and feed and water consumption was observed regularly at the end of the study.

Results: The main finding of the study for the test extract was that the petroleum ether extract of BR leaves prevented a rise in blood glucose level in STZ induced diabetic animal. Furthermore, extract showed significant antiadipogenic and antihyperlipidemic effect. It improved lipid profile by decreasing the levels of serum triglycerides, total cholesterol, low-density lipoprotein (LDL) and increasing high-density lipoprotein $(\mathrm{HDL})$ cholesterol. Extract exhibited the concentration-dependent inhibitory effect with an $\mathrm{IC}_{50}$ value of $660.26 \mu \mathrm{g} / \mathrm{ml}$.

Conclusions: It can be concluded from the study that BR extract posses signigicant antidiabetic activity by reducing blood glucose level of diabetic rats. It also normalized adipose tissues and lipid level. Due to its potential, it may be an effective drug for treatment of diabetes and related complications like obesity and dyslipidemia.
\end{abstract}

Keywords: Adipocyte differentiation assay, Oral glucose tolerance test, Diabetes, Hyperlipidemia, Obesity

\section{Background}

Diabetes mellitus is a metabolic disorder characterized by abnormal carbohydrate, protein and fat metabolism due to deficient insulin action on target tissues which results in hyperglycemia [1]. Diabetes mainly is of two types Type-1 and Type-2 diabetes i.e. insulin dependent diabetes mellitus (IDDM) and non-insulin dependent diabetes mellitus (NIDDM) respectively [2, 3]. According to International Federation of Diabetes report it is estimated that 387 million people have been suffering from diabetes till 2014, in which $90 \%$ cases of type- 2 diabetes. The numbers of

\footnotetext{
* Correspondence: paragjain1510@gmail.com

${ }^{3}$ Department of Pharmacology, Institute of Pharmaceutical Sciences, Guru

Ghasidas Vishwavidyalaya Koni, Bilaspur, (C.G.) 495009, India

Full list of author information is available at the end of the article
}

diabetic people are expected to rise to 592 million by 2035 [4]. Increase incidence of visceral obesity is closely associated with the risk of diabetes mainly Type-2 diabetes [5]. There is a pronounced correlation between an increased quantity of visceral fat, metabolic disorder and heart related diseases [6].

Bauhinia racemosa Lam. (BR) belongs to the family Caesalpiniaceae, popularly known as 'Sonpatti' in India. Its leaves are simple, bilobed, and alternate; stipules small, caducous, petiole $10-33 \mathrm{~mm}$ long, slender, pubescent, swollen at the base and at the tip. Poor and harsh climate is favorable for its growth of rare medicinal tree. The tree is widely distributed throughout India, Srilanka, Ceylon, China and Timor [7]. The deciduous tree is propagated easily from seed. Almost each \& every part 
of this tree has some medicinal values. The tree has small, creamy white or yellow colored flowers in axillary or terminal racemes. The flowers of BR are laxative \& seeds are anti-bacterial [8] and [9]. BR commonly used in the treatment of diabetes, however, its other species like Bauhinia vahlii, Bauhinia variegata, Bauhinia purpurea, Bauhinia tomentosa has been used as antidiarrhoeal, antispasmodic, anti-inflammatory, carminative, vermicidal and hepatoprotective activity [10, 11]. The tree yields a useful gum \& fibers, bark is used for dyeing. Juice of BR which is extracted from the tender shoots is mixed with mother's milk and used to clean and cool eyes. The bark fiber is used to make ropes to make ladders and to tie cows [12].

The phytochemistry of Bahuinia revealed the presence of a new tetracyclic lupeol, betulin, $\beta$-sitosterol, and tetracyclic 2, 2-dimethyl chroman isolated from the roots [13]. Stem bark revealed the presence of alkaloids, glycosides, carbohydrates, saponins, flavonoids, triterpenoids (ß-amyrin), anthroqunonine, steroid ( $ß$-sitosterol) stilbene (resveratrol) [14] and [15]. It has been reported that different plant isolates possess insulin releasing, pancreatic beta cells re-generating and fighting the insulin resistance problems.

\section{Methods}

\section{Collection, authentication and extraction}

Leaves of BR were collected from forest of Ambikapur $\left(23.1200^{\circ} \mathrm{N}, 83.2000^{\circ} \mathrm{E}\right)$ district of Chhattisgarh in the month of December 2014 authenticated by Dr. N. K. Satti, Department of Natural Products, Institute of Integrative Medicine, Jammu, and leaves were deposited in the herbarium of the Institute. $1 \mathrm{~kg}$ leaves of BR were extracted with petroleum ether by cold percolation at b.p. $40-60{ }^{\circ} \mathrm{C}$ and percentage yield was found to be $6.42 \%$. The extract was dried with the help of evaporator (Buchi, USA) under reduced pressure, temperature (37 $40{ }^{\circ} \mathrm{C}$ ). Dried extract was placed in an airtight container and further used for studies as antidiabetic, antiadipogenic, and hypolipidemic studies [16].

\section{Phytochemical screening}

The petroleum ether extract of BR leaves was subjected to different chemical tests separately for identification of various active constituents employing standard protocols recommended by WHO [17].

\section{Experimental animals}

Wistar rats were selected for the study weighing 170190 g. Experimental protocol was prepared to take the minimum number of animals for in-vivo and acute toxicity study and selected animals were approved by the Institutional Animal Ethical Committee (IAEC reg no-
68/99/CPCSEA/reg) of Indian Institute of Integrative Medicine (IIIM), CSIR, Jammu. The animals kept in the arrangement of $12 \mathrm{~h}$ light and $12 \mathrm{~h}$ dark conditions with temperature maintained at $22 \pm 2{ }^{\circ} \mathrm{C}$ and humidity $47 \pm$ $65 \%$. Pelleted diet was used for animals feeding throughout the study and water ad libitum. Animals were divided into five different groups as normal control (NC), diabetic control (DC), reference group (RG), test group-1 (BR-1) (250 mg/kg), test group-2 (BR-2) (500 mg/kg) each group containing six animals.

\section{Cell line}

3T3-L1 cell line was used for evaluating in vitro antiadipogenic activity which was procured from National Centre for Cell Science (NCCS), Pune, India.

\section{Chemicals used}

Dexamethasone, Dimethyl sulfoxide (DMSO), Dulbecco's modified Eagle's medium (DMEM), Fetal bovine serum (FBS), Gentamycin, Insulin, Penicillin, Phosphate Buffer Saline (PBS), Roswell Park Memorial Institute medium (RPMI), Streptomycin, Trypsin, Sodium Pyruvate were purchased from Sigma Chem. Co., USA. Other chemicals are Cholesterol (Qualigens fine chem., glaxo India Ltd.), Ethylenediamine tetraacetic acid, disodium salt (EDTA) (HiMedia Laboratories Pvt. Ltd., Mumbai), Formaldehyde (Qualigens fine chem., glaxo India Ltd.), 3-isobutyl-1methylxanthine (IBMX), Isopropyl alcohol (Sisco Research Laboratories. Pvt. Ltd., Mumbai), Sodium bicarbonate $\left(\mathrm{NaHCO}_{3}\right)$ (HiMedia Laboratories Pvt. Ltd., Mumbai), Oil Red O Dye, Blood glucose, Triglyceride, Total Cholesterol, FFA estimation kits (Siemens Medical Solutions Diagnostics Ltd., Baroda, Gujarat, India), Rat Insulin ELISA kit (Mercodia, Sweden), Simavastatin, Glibenclamide (Nicholas Piramal Research Limited Mumbai).

\section{Pharmacological screening methods In-vitro methods}

In-vitro cytotoxicity assay 3T3-L1 cell line was assayed by Neutral Red Assay in order to determine in vitro toxicity of petroleum ether extract of BR-1 and BR-2. The cell line was cultured in DMEM complete media using $150 \mathrm{~cm}^{2}$ culture flasks with temperature maintained at $37{ }^{\circ} \mathrm{C}$ allowing $5 \% \mathrm{CO}_{2}$ and relative humidity more than $90 \%$. Test extract was diluted appropriately in DMEM medium, were added to the cells and again incubated for 48 h. Cells viability was determined using Neutral Red Assay procedure. Briefly, cells were seeded $2.5 \times 10^{4}$ cells/well at temperature maintained $37{ }^{\circ} \mathrm{C}$ and allowed to grow undistributed for $24 \mathrm{~h}$ then cell counts were made by using the Trypan Blue exclusion method to determine viability of cells [18]. Cell containing extract was exposed in the presence and absence of UV light. Cell observed under UV light was labelled as light extract 
(LE) however dark extract (DE) was named when extract observed in dark. After incubating with samples, the cells were washed with saline and incubated for $90 \mathrm{~min}$ with the medium containing Neutral Red (166 ug/ml). On addition of isopranol $(0.33 \% \mathrm{HCl})$ to lyses the cells; as a result, the incorporated dye was liberated from the viable cells. The absorbance was measured at $540 \mathrm{~nm}$ on a Microplate Reader (Molecular Devices, SPECTRAMAX plus 384). All the assays were performed in triplicate. The above procedure was performed as per our previous work [18]. Viability of cell was calculated by the using the formula below at $540 \mathrm{~nm}$ absorbance in light and dark conditions.

$$
\% \text { Viability }=\frac{\text { OD sample } \mathrm{X} 100}{\text { OD negative control }}
$$

Here, OD (Optical Density/Absorbance), OD sample = absorbance of cell at different dose, OD negative control = absorbance of $100 \%$ viable cell

Dose response curve for the toxicity studies Dose response curve of BR extract for 3T3-L1 cell line is shown in Fig. 1. Extract exhibited concentration-dependent inhibitory effect with an $\mathrm{IC}_{50}$ value of $660.26 \mu \mathrm{g} / \mathrm{ml}$.

Adipocyte Differentiation assay Differentiation was induced by subculture and seeding of preadipocyte cell line. Cells were harvested from $25 \mathrm{~mm}$ tissue culture flask when the cells around 70 to $80 \%$ confluent by using trypsinization. 96 well plate $\left(2 \times 10^{3}\right.$ cells/well cell density and volume of media per well $100 \mu \mathrm{l}$ ) tissue culture vessels was used for seeding of cells in complete media. Cells were growing for 2 days to reach $100 \%$ confluency. Cells were kept for another $48 \mathrm{~h}$ in this state, to arrest the cell division, then treated with adipocyte differentiation media (1 $\mu \mathrm{M}$ Dexamethasone, $0.5 \mathrm{mM}$ 3-Isobutyl-1-methylxanthine, $10 \mu \mathrm{g} / \mathrm{ml} \mathrm{Insu-}$ lin and complete media). Cells were feeded with adipocyte differentiation media after post confluency. Test extract was evaluated in different dose of 50, 100 and $200 \mu \mathrm{g} / \mathrm{ml}$ at day 0 for adipocyte differentiation assay and kept the cells for $96 \mathrm{~h}$ in this state. All the media were discarded after $96 \mathrm{~h}$ by gentle pipetting. Cells were easily detachable from plate at this stage. At $4^{\text {th }}$ day adipocyte differentiation media

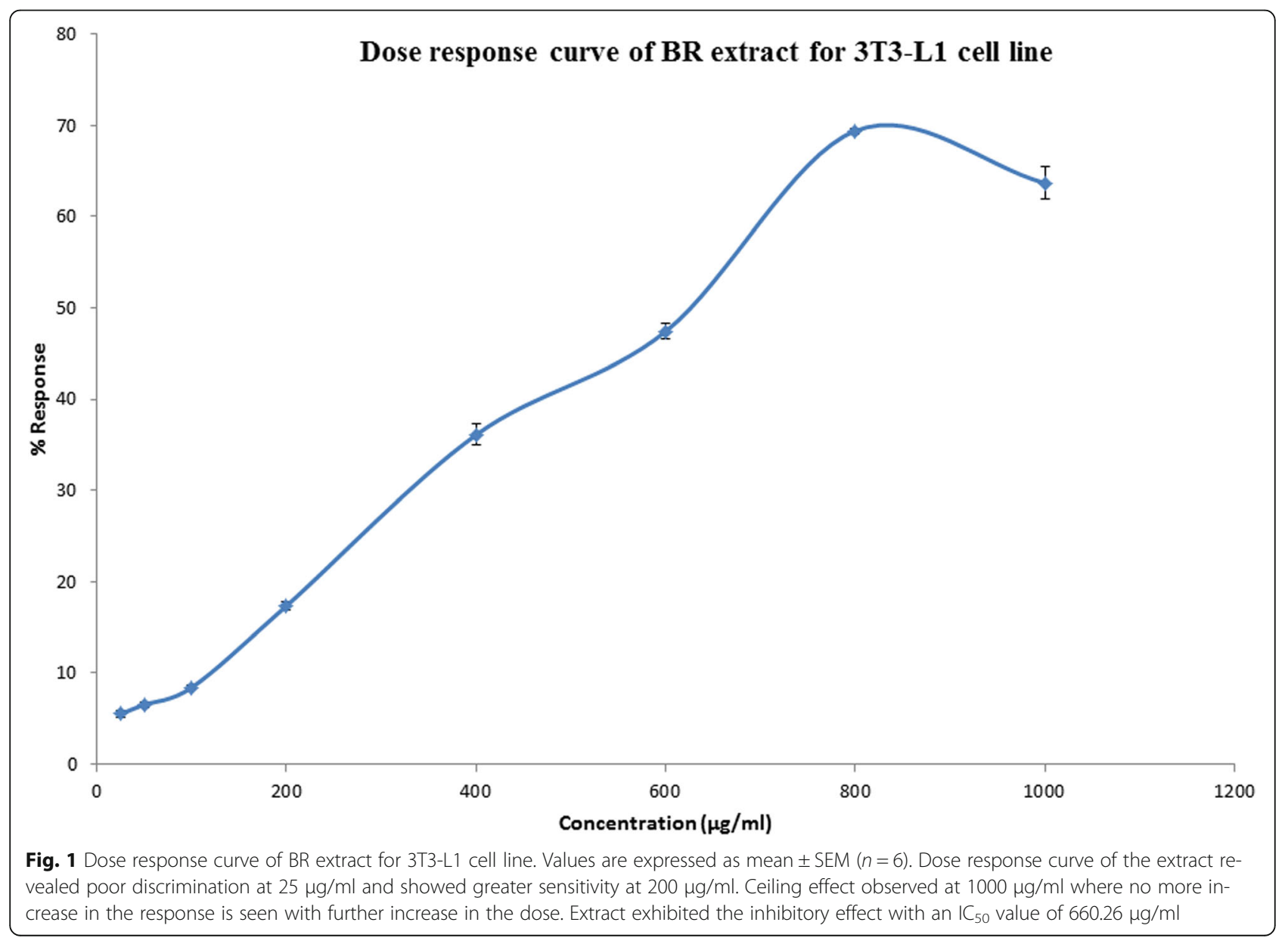


was added by subsequent changes in every 2 days. Lipid droplets were visible inside the cells after $8^{\text {th }}$ day and droplets enlarges at around the $14^{\text {th }}$ day. After day 8, water was removed and kept it in dry. Elute oil Red $\mathrm{O}$ by adding $100 \%$ isopropanol incubated for $10 \mathrm{~min}$ OD measurement at $540 \mathrm{~nm}$ in spectrophotometer [19]. Extract was evaluated at both light and dark conditions at $540 \mathrm{~nm}$ absorbance and determine percentage cell inhibition using the formula below:

$$
\% \text { Cell inhibition }=\frac{\text { Control absorbance- Test absorbance }}{\text { Control absorbance }} \times 100
$$

\section{In-vivo experimental methods}

Acute toxicity study The acute toxicity study was carried out on male Wistar rats weighing 150-200 g by administering extract orally at one of the levels (150, $500,1000,2000 \mathrm{mg} / \mathrm{kg}$ ) once only. The dose that shows toxicity signs/morality is the toxic dose and $1 / 10^{\text {th }}$ of this toxic dose is considered for therapeutic exploration [20]. Toxicity study of extracts was performed as per OECD guideline No.423.

Eighteen hours fasted Rat model Male Wistar rats, six animals in each group were fasted overnight. Blood glucose determination was done initially at $0 \mathrm{~h}$ prior to drug treatment and finally at $3 \mathrm{~h}$ after drug treatment has over. Animals were divided into four groups, namely normal control $1 \% \mathrm{v} / \mathrm{v}$ Tween $80(10 \mathrm{ml} / \mathrm{kg})$, reference group (glibenclamide; $5.0 \mathrm{mg} / \mathrm{kg}$ ), test group; BR-1 (250 mg/kg extract) and BR-2 (500 mg/kg extract).

Oral Glucose Tolerance Test (OGTT) Oral glucose tolerance test was performed on overnight fasted male Wistar rats. Animals were divided into different groups as normal control (untreated), glucose primed control, reference group (glucose primed + glibenclamide), test groups (glucose primed + test extract). Glucose was given in the dose of $1.5 \mathrm{~g} / \mathrm{kg}$ of $10 \%$ solution to all groups except normal control. Estimation of blood was done at $0 \mathrm{~min}$ (prior to any treatment), $30 \mathrm{~min}$ and $90 \min [21]$.

Induction of diabetes in rats Diabetes was induced by single intraperitoneal injection of freshly prepared STZ (65 mg/kg body weight) in $0.1 \mathrm{M}$ citrate buffer ( $\mathrm{pH} 4.5$ ) in a volume of $1 \mathrm{ml} / \mathrm{kg}$ body weight. Nicotinamide was given in the dose of $110 \mathrm{mg} / \mathrm{kg}$ prior to induction of diabetes to reduce the beta cytotoxic effect of streptozotocin. Diabetes was established in these STZ treated rats over a period of 4 days. The control animals were treated with citrate buffer ( $\mathrm{pH} 4.5)$. After 4 days blood was collected from the retro-orbital route and the plasma glucose level of each rat was determined. Animals were evaluate by using glucometer and considered diabetic when fasting blood glucose (FSG) level higher than $250 \mathrm{mg} / \mathrm{dL}$ [22].

Treatment Protocol for STZ induced diabetic rats model The diabetic rats were divided randomly into five different groups, each containing six animals. Normal and Diabetic control animal groups received $1 \% \mathrm{v} / \mathrm{v}$ Tween 80 (1 ml/kg p.o.), Reference group received glibenclamide $5.0 \mathrm{mg} / \mathrm{kg}$ p.o. and extract of BR was given in the doses of 250 and $500 \mathrm{mg} / \mathrm{kg}$ in $1 \% \mathrm{v} / \mathrm{v}$ of Tween 80 ( $1 \mathrm{ml} / \mathrm{kg}$ p.o.) for a period of 28 days to different treatment groups. The blood sample was collected on $0,7,14,21$ and 28 days.

Blood glucose Blood glucose was estimated by glucose oxidase/peroxidase (GOD/POD) method using a commercially available enzymatic kit from Siemens Medical Solutions Diagnostics Ltd., Baroda and Gujarat, India. The absorbance of the test samples and reference was measured against blank at $505 \mathrm{~nm}$ spectrophotometrically. The concentration of the glucose was calculated using the following formula:

$$
\text { Concentration of glucose }=\frac{\text { Optical density of test }}{\text { Optical density of standard }\left(\frac{\mathrm{mg}}{\mathrm{dl}}\right)} \times 100
$$

Insulin ELISA The principle of the Rat Insulin ELISA is based on a solid phase two-site enzyme immune assay. It is based on the direct Sandwich technique in which two monoclonal antibodies are directed against separate antigenic determinants on the insulin molecule. During incubation insulin in the sample reacted with peroxidase-conjugated anti-insulin antibodies and bound to microtitration well. A simple washing step removes the unbound enzyme labeled antibody. The bound conjugate was detected by reaction with $3,3 \beta$, 5 , $5 \beta$-tetramethylbenzidine. The reaction was stopped by adding acid to give a colorimetric endpoint that was read spectrophotometrically [23].

Lipid profile Different lipid parameters in blood like Triglycerides (TGs), Total Cholesterol (TC), low density lipoprotein (LDL), high density lipoprotein (HDL) were estimated using suitable assay procedures. Triglycerides are the chemical form in which most fat exists in food as well as in the body. Triglycerides (TGs) were determined by enzymatic colorimetric method (Adipogenesis assay kit). Triglyceride concentration in the sample was measured at $546 \mathrm{~nm}$. The determination of serum cholesterol was considered to be significant in Diabetes Mellitus and various other diseases. Total cholesterol (TC) was estimated by the enzymatic method as 
described by [24]. HDL and LDL were estimated using commercial kits procured from Bayer Diagnostics \& Siemens Healthcare, India with the aid of a clinical chemistry analyser Chem-7 (Erba, Manheim, Germany).

Statistical analysis All values were expressed as Mean \pm SEM. The results were analyzed statistically using two way analysis of variance (ANOVA) followed by Bonferroni post-tests to calculate the level of significance. Values are expressed as mean \pm SEM (Number of animals, $n=6$ ); significantly different at $" p<0.05, * p<0.01, * * * p<0.001$, when compared with diabetic control group.

\section{Result}

\section{Phytochemical screening}

The preliminary phytochemical screening of BR petroleum ether extract revealed the presence of saponins, sterols, carbohydrates, flavonoids, triterpenes and proteins.

\section{In-vitro methods}

\section{In vitro toxicity of BR extract on 3T3-L1 cell lines}

The BR extract was exposed to two different conditions of dark (DE) and light (LE) conditions. In vitro toxicity of BR extract was evaluated on 3T3-L1 cell lines by Neutral Red assay at different concentrations of 200, 100,50 and $25 \mu \mathrm{g} / \mathrm{ml}$; all the concentration showed more than $75 \%$ viability. However the extract exposed in dark condition exhibited more viability of cells at different concentrations as compared to light condition (Table 1).

\section{Antiadipogenic activity of BR extract on 3T3-L1 cell line}

BR extract showed significant antiadipogenic activity in both dark and light conditions. However the percentage inhibition of adipocyte cells by the extract in dark condition at the concentration $200 \mu \mathrm{g} / \mathrm{ml}$ was found to be $41.66 \%$, which was lesser than the standard drug simvastatin (51.83\%). The antiadipogenic effect of the BR extract on 3T3-L1 cell Line is shown in Table 2.

\section{In-vivo experimental methods Acute toxicity study}

An acute toxicity study revealed that BR extract did not produce any toxic sign and symptoms even no any mortality when administered per orally to rats at a dose

Table 1 In vitro toxicity of BR extract on 3T3-L1 cell lines

\begin{tabular}{|c|c|c|c|c|}
\hline \multirow[t]{3}{*}{ Group } & \multicolumn{4}{|l|}{$\%$ Viability } \\
\hline & \multicolumn{4}{|c|}{ Concentration $(\mu \mathrm{g} / \mathrm{ml})$} \\
\hline & 25 & 50 & 100 & 200 \\
\hline $\mathrm{DE}$ & $93.33 \pm 0.84$ & $88.00 \pm 0.73$ & $83.33 \pm 0.71$ & $79.00 \pm 0.25$ \\
\hline LE & $91.33 \pm 1.11$ & $85.00 \pm 1.06$ & $80.16 \pm 0.60$ & $76.66 \pm 0.66$ \\
\hline
\end{tabular}

$\mathrm{LE}=\mathrm{BR}$ extract evaluated under $\mathrm{UV}$ light, $\mathrm{DE}=\mathrm{BR}$ extract evaluated in dark condition. Values are expressed as mean \pm SEM (Number of experiments $=6$ ) significantly different at ${ }^{*} p<0.05,{ }^{* *} P<0.01,{ }^{* *} P<0.001$
Table 2 Antiadipogenic activity of BR extract on 3T3-L1 cell Lines

\begin{tabular}{|c|c|c|c|c|}
\hline \multirow[t]{2}{*}{ S. N. } & \multirow[t]{2}{*}{ Group } & \multicolumn{3}{|c|}{$\begin{array}{l}\text { \% Inhibition } \\
\text { Concentration ( } \mu \mathrm{g} / \mathrm{ml})\end{array}$} \\
\hline & & 50 & 100 & 200 \\
\hline 1. & $\mathrm{LE}$ & $20.66 \pm 1.28$ & $31.16 \pm 1.47$ & $39.33 \pm 0.88$ \\
\hline 2. & $\mathrm{DE}$ & $23.16 \pm 0.65$ & $33.83 \pm 1.32$ & $41.66 \pm 1.05$ \\
\hline 3. & Simvastatin & $32.50 \pm 1.36$ & $41.33 \pm 0.49$ & $51.83 \pm 1.85$ \\
\hline
\end{tabular}

$\mathrm{LE}=\mathrm{BR}$ extract evaluated under UV light (Light extract), $\mathrm{DE}=\mathrm{BR}$ extract evaluated in dark condition (Dark extract)

Values are expressed as mean \pm SEM (Number of experiments $=6$ ) significantly different at ${ }^{*} p<0.05,{ }^{* *} P<0.01,{ }^{* * *} P<0.001$

up to $2000 \mathrm{mg} / \mathrm{kg}$. According to the dose safety level upto $2000 \mathrm{mg} / \mathrm{kg}$ two doses of BR extract, i.e. 250 and $500 \mathrm{mg} / \mathrm{kg}$ were selected for in-vivo antidiabetic study.

Effect of BR extract on eighteen hours fasted Rat model The BR extract was found effective in reducing blood glucose level on eighteen hour fasted rat model. However reduction in blood glucose level by the extract BR-2 was found to be $58.8 \mathrm{mg} / \mathrm{dl}$, which was nearly equal to reference drug glibenclamide $(51.4 \mathrm{mg} / \mathrm{dl})$ after $3 \mathrm{~h}$. The results of reduction in blood glucose level by BR extracts have been summarized in Fig. 2.

Effect of BR extract on Oral Glucose Tolerance Test (OGTT)

In this model blood glucose level was evaluated on three time points, i.e. $0 \mathrm{~min}, 30 \mathrm{~min}$ and $90 \mathrm{~min}$ in glucose primed rats. Reduction in glucose level by BR-2 was significant at $90 \mathrm{~min}$ i.e. $115.65 \mathrm{mg} / \mathrm{dl}$, which was closer to $90.44 \mathrm{mg} / \mathrm{dl}$ of reference group. Glucose level was increased at $30 \mathrm{~min}$ in all treatment groups, but it was reduced in a significant manner at $90 \mathrm{~min}$ (Table 3).

\section{STZ Induced diabetes model}

Effect of BR extract on fasting blood glucose level Administration of the BR extract to STZ induced diabetic rats caused a significant reduction in fasting serum glucose (FSG) at level in the doses of 250 and $500 \mathrm{mg} / \mathrm{kg}$. Reduction in FSG level was dose dependent, i.e. $134.70 \mathrm{mg} / \mathrm{dl}$ for BR-2 and $143.88 \mathrm{mg} / \mathrm{dl}$ for BR-1 as revealed on day $28^{\text {th }}$. Weekly change in FSG level of different dose groups and its comparison with the diabetic control group has been summarized in the Table 4 .

Effect of BR extract on insulin level in diabetic rats Insulin level was measured on day 1 was considered as initial reading and finally on day 28 as a final reading. BR extract caused a significant rise in the level of insulin in STZ induced diabetic rats. Insulin level was found to be $0.49 \mathrm{mg} / \mathrm{dl}$ for BR-2 extract on day 28 which was closer to the reference group i.e. glibenclamide $(0.58 \mathrm{mg} / \mathrm{dl})$. Effect of the BR extract on insulin level of 


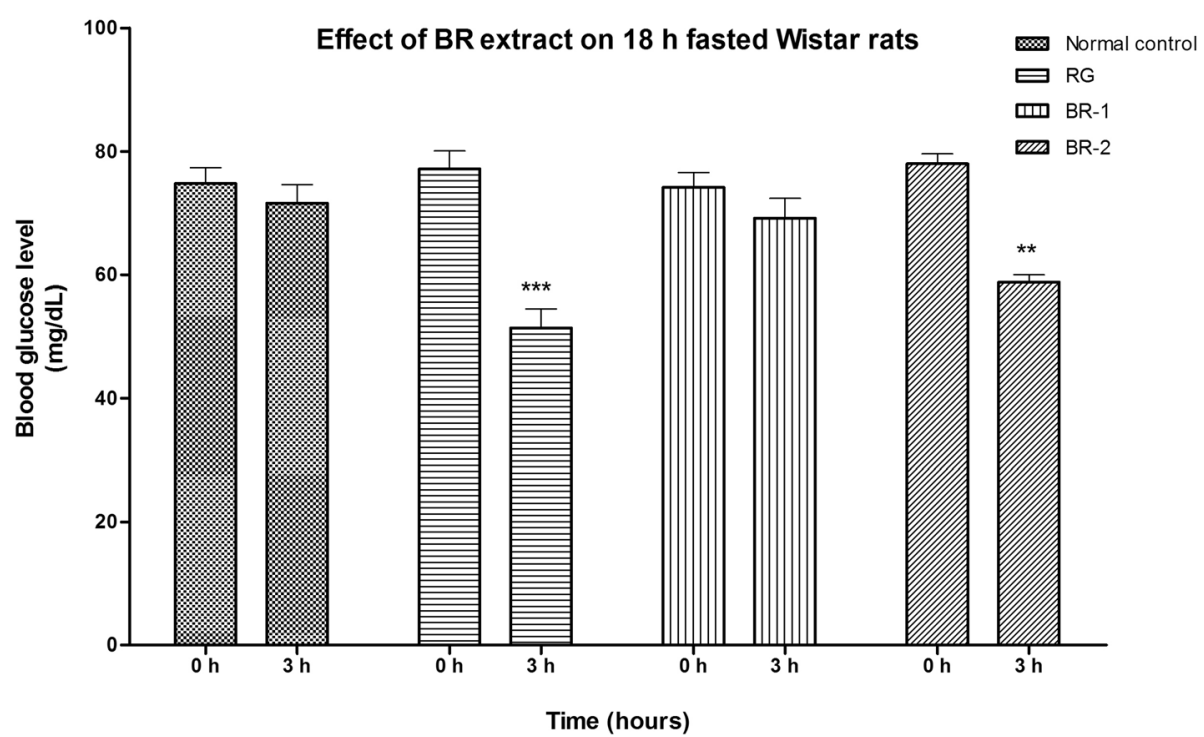

Fig. 2 Effect of BR extract on $18 \mathrm{~h}$ fasted Wistar rats. $N C=$ Normal control, $R G=$ Reference group (glibenclamide), BR-1 = BR extract in dose of $250 \mathrm{mg} / \mathrm{kg}, \mathrm{BR}-2=$ BR extract in dose of $500 \mathrm{mg} / \mathrm{kg}$. Values are expressed as mean \pm SEM (Number of animals, $n=6$ ); significantly different at, ${ }^{*} p<0.05,{ }^{*} P<0.01,{ }^{* *} P<0.001$ when compared to control group at $0 \mathrm{~h}$ blood glucose level

STZ induced diabetic rats is graphically summarized in Fig. 3.

Effect of BR extract on lipid profile in diabetic rats STZ-induced diabetic rats having an increased amount of cholesterol, LDL and triglyceride as compared to their respective values in control animals. Administration of glibenclamide and BR-2 extract caused a significant reduction in the lipid profile of diabetic rats, i.e. $53.75 \mathrm{mg} / \mathrm{dl}$ and $57.66 \mathrm{mg} / \mathrm{dl}$ respectively. BR-2 extract exhibited an increase in the level of HDL $(52.74 \mathrm{mg} / \mathrm{dl})$ with a decrease in TG $(87.34 \mathrm{mg} / \mathrm{dl})$ and TC $(117.38 \mathrm{mg} / \mathrm{dl})$ levels. Lipid profile of STZ-induced diabetic rats has been summarized in Table 5 .

Effect of BR extract on body weight of diabetic rats STZ caused an abrupt decrease in body weight of animals. However treatment of diabetic animals with BR extract revealed a significant rise in body weight in a weekly pattern and the results were closer to the reference group animals (Fig. 4). At the end of the study on day 28 the body weight of BR-2 treated animals was found to be $183.48 \mathrm{gm}$ which was equal to reference group animals i.e. $184.31 \mathrm{gm}$.

\section{Discussion}

This study suggested that BR possess definite antidiabetic, hypolipidemic and antiadipogenic activity in STZ-induced diabetic rats. BR extract showed a dose dependent fall in FSG with 250 and $500 \mathrm{mg} / \mathrm{kg}$ dose in experimental diabetic animals. Moreover, the daily administration of the BR extract to STZ-diabetic rats for four weeks caused a significant reduction in food and water intakes, and an increase in the body weight. STZ is a cytotoxic compound which induces

Table 3 Effect of BR extract on blood glucose level of glucose primed rats

\begin{tabular}{|c|c|c|c|c|c|}
\hline \multirow[t]{2}{*}{ S. N. } & \multirow[t]{2}{*}{ Group } & \multirow[t]{2}{*}{ Dose $(\mathrm{mg} / \mathrm{kg})$} & \multicolumn{3}{|c|}{ Blood Glucose Level (mg/dl) } \\
\hline & & & $0 \mathrm{~min}$ & $30 \min ^{\#}$ & 90 min $^{\#}$ \\
\hline 1. & NC & Untreated & $77.71 \pm 0.87$ & $78.02 \pm 0.79$ & $78.68 \pm 1.13$ \\
\hline 2. & GPC & Vehicle & $81.32 \pm 1.08$ & $172.91 \pm 1.85^{* * *}$ & $178.65 \pm 1.13^{* * *}$ \\
\hline 3. & RG + glucose & 5.0 & $79.34 \pm 0.80$ & $152.87 \pm 2.12^{* * *}$ & $90.44 \pm 2.42^{* * *}$ \\
\hline 4. & BR-1+ glucose & 250 & $82.30 \pm 1.15$ & $157.78 \pm 2.45^{* * *}$ & $123.57 \pm 3.49^{* * *}$ \\
\hline 5. & BR-2+ glucose & 500 & $81.97 \pm 1.04$ & $152.92 \pm 1.02^{* * *}$ & $115.65 \pm 1.45^{* * *}$ \\
\hline
\end{tabular}

"Time post glucose administration. NC = Normal control, GPC = glucose primed control, RG = Reference group (glibenclamide), BR-1 = BR extract in dose of $250 \mathrm{mg} / \mathrm{kg}, \mathrm{BR}-2=\mathrm{BR}$ extract in dose of $500 \mathrm{mg} / \mathrm{kg}$

Values are expressed as mean \pm SEM (Number of animals $=6$ ) significantly different at ${ }^{*} p<0.05,{ }^{* *} p<0.01,{ }^{* * *} p<0.001$ 
Table 4 Effect of BR extract on STZ induced diabetes in rats

\begin{tabular}{|c|c|c|c|c|c|c|c|}
\hline \multirow[t]{2}{*}{ S. N. } & \multirow[t]{2}{*}{ Group } & \multirow[t]{2}{*}{ Dose (mg/kg) } & \multicolumn{5}{|c|}{ Blood Glucose Level (mg/dL) } \\
\hline & & & Day 0 & Day 7 & Day 14 & Day 21 & Day 28 \\
\hline & NC & untreated & $79.12 \pm 0.78$ & $89.83 \pm 1.10$ & $86.36 \pm 1.03$ & $87.60 \pm 1.43$ & $87.46 \pm 2.37$ \\
\hline & DC & vehicle & $80.20 \pm 0.56$ & $370.04 \pm 6.28$ & $338.30 \pm 13.18$ & $297.97 \pm 2.66$ & $297.76 \pm 2.97$ \\
\hline & RG & 5.0 & $81.35 \pm 0.49$ & $353.33 \pm 3.49^{* *}$ & $261.48 \pm 2.69^{* * *}$ & $182.82 \pm 3.18^{* * *}$ & $122.70 \pm 3.26^{* * *}$ \\
\hline & BR-1 & 250 & $81.37 \pm 0.47$ & $361.00 \pm 2.80$ & $281.10 \pm 2.55^{* * *}$ & $204.49 \pm 3.79^{* * *}$ & $143.88 \pm 2.06^{* * *}$ \\
\hline & BR-2 & 500 & $79.72 \pm 0.74$ & $355.41 \pm 3.17^{*}$ & $264.23 \pm 2.56^{* * *}$ & $191.24 \pm 2.69^{* * *}$ & $134.70 \pm 1.58^{* * *}$ \\
\hline
\end{tabular}

$\mathrm{NC}=$ Normal control, $\mathrm{DC}=$ Diabetic control, RG = Reference group (glibenclamide), BR-1 = BR extract in dose of $250 \mathrm{mg} / \mathrm{kg}, \mathrm{BR}-2=\mathrm{BR}$ extract in dose of 500 mg/kg Values are expressed as mean \pm SEM (Number of animals $=6$ ) significantly different at ${ }^{*} p<0.05,{ }^{* *} p<0.01,{ }^{* * *} p<0.001$

diabetes by damaging $\beta$ pancreatic cells that causes a reduction in insulin release. [25], reported that extracts of medicinal plants causes activation of $\beta$ cells as an antidiabetic effect and hence showing insulinogenic action. STZ causes persistent hyperglycemia through destruction of pancreatic $\beta$-cells (type-I diabetes mellitus). The possible mechanism through which BR extracts showed an antidiabetic effect might have been due to increased utilization of glucose by peripheral tissues, improved sensitivity of target tissues for insulin or it may be due to $\beta$-cell stimulation. Extract of BR exhibited hypocholesterolemic and hypotriglyceridemic effects, while increasing the levels of HDL in diabetic rats. These findings have been well justified by various reports in the literature stating that some medicinal plants show antidiabetic as well as hypolipidemic effects [26].
The elevation of serum insulin in BR extract treated STZ-induced diabetic rats could either be due to the insulinotropic substances present in the extract, which induce the intact functional $\beta$-cells to produce insulin, or the protection of the functional $\beta$-cells from further deterioration so that they remain active and produce insulin. Similarly the extracts of Medicago sativa [27], Eucalyptus globulus [25, 28] and Sambucus nigra [29] have been reported to possess antidiabetic property by insulin-releasing action. Since insulin inhibits the activity of Glc-6-Pase in the liver of diabetic rats and controls hepatic glucose production (HGP), the insulinotropic effect of BR might play an immense role in the control of diabetes in STZ-induced diabetic rats. The suppression of Glc-6-P hydrolysis could also be one of the reasons for the hypoglycemic effect of the BR extract in diabetic rats. The improvement in lipid

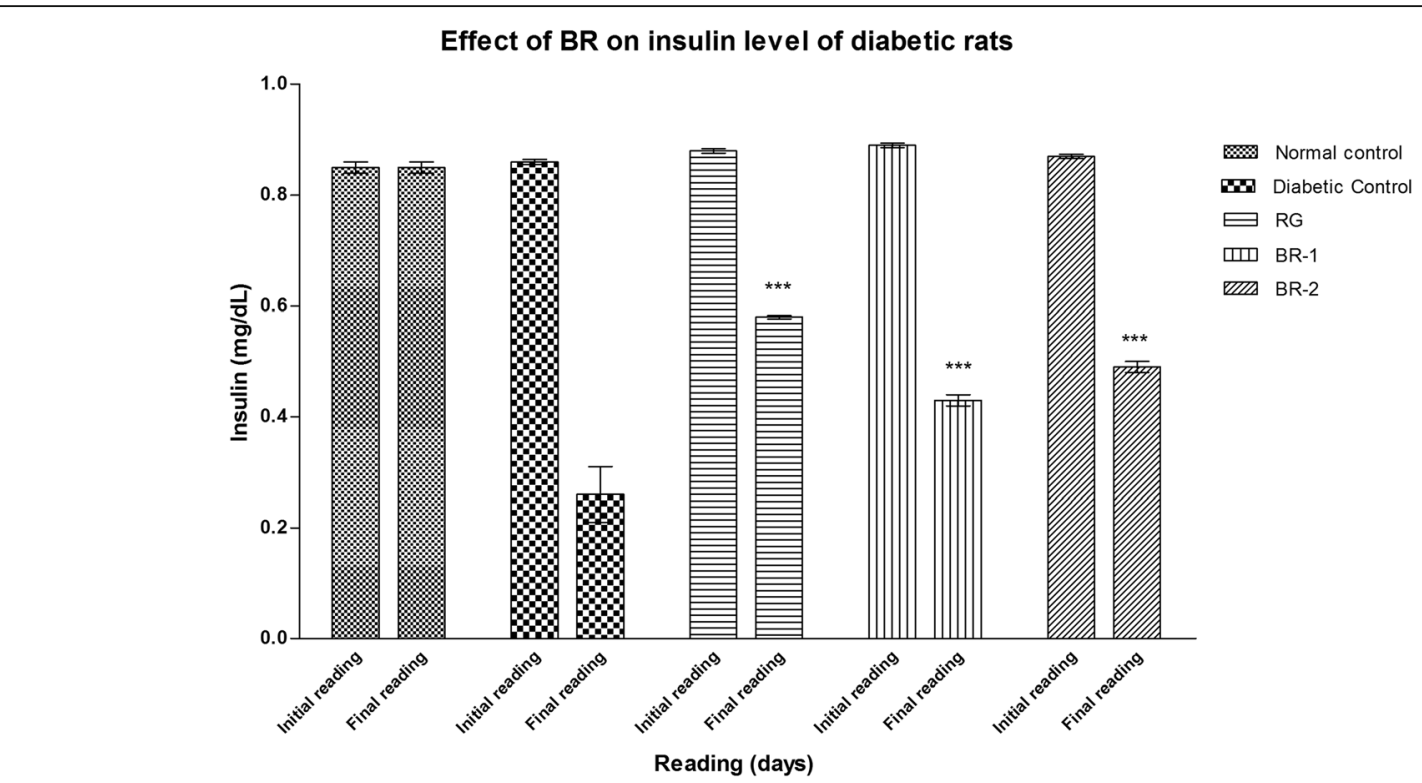

Fig. 3 Effect of BR extract on Insulin Level of STZ induce diabetes rats. NC = Normal control, DC= Diabetic control, RG = Reference group (glibenclamide), $\mathrm{BR}-1=\mathrm{BR}$ extract in dose of $250 \mathrm{mg} / \mathrm{kg}, \mathrm{BR}-2=\mathrm{BR}$ extract in dose of $500 \mathrm{mg} / \mathrm{kg}$. Values are expressed as mean \pm SEM (Number of animals, $n=6$ ); significantly different at, ${ }^{*} p<0.05,{ }^{* *} p<0.01,{ }^{* * *} p<0.001$ when compared with diabetic control group 
Table 5 Effect of BR extract on Lipid profile of STZ induced diabetes in rats

\begin{tabular}{|c|c|c|c|c|c|c|}
\hline \multirow[t]{2}{*}{ S. N. } & \multirow[t]{2}{*}{ Group } & \multirow[t]{2}{*}{ Dose (mg/kg) } & \multicolumn{4}{|c|}{ Lipid profile (mg/dL) } \\
\hline & & & $\mathrm{TG}$ & $\mathrm{TC}$ & $\mathrm{HDL}$ & $\mathrm{LDL}$ \\
\hline 1 & NC & Untreated & $88.90 \pm 0.92$ & $97.08 \pm 1.003$ & $57.37 \pm 0.57$ & $47.52 \pm 0.57$ \\
\hline 2 & DC & Vehicle & $106.47 \pm 2.12$ & $148.91 \pm 0.80$ & $33.39 \pm 1.27$ & $105.16 \pm 3.61$ \\
\hline 3 & $R G$ & 5.0 & $85.88 \pm 0.34^{* * *}$ & $106.00 \pm 0.40^{* * *}$ & $57.30 \pm 0.65^{* * *}$ & $53.75 \pm 0.78^{* * *}$ \\
\hline 4 & BR-1 & 250 & $89.84 \pm 0.78^{* * *}$ & $126.29 \pm 1.37^{* * *}$ & $45.14 \pm 1.32^{* * *}$ & $60.14 \pm 1.31^{* * *}$ \\
\hline 5 & BR-2 & 500 & $87.34 \pm 0.77^{* * *}$ & $117.38 \pm 0.75^{* * *}$ & $52.74 \pm 0.44^{* * *}$ & $57.66 \pm 1.21^{* * *}$ \\
\hline
\end{tabular}

$\mathrm{NC}=$ Normal control, DC $=$ Diabetic control, RG = Reference group (glibenclamide), BR-1 = BR extract in dose of $250 \mathrm{mg} / \mathrm{kg}, \mathrm{BR}-2=\mathrm{BR}$ extract in dose of 500 mg/kg Values are expressed as mean \pm SEM (Number of animals $=6$ ) significantly different at ${ }^{*} p<0.05,{ }^{* *} p<0.01,{ }^{* * *} p<0.001$

profile by these extracts also supports their antidiabetic activity along with antihyperlipidemic activity [30].

BR extract showed more than $75 \%$ of viability of cells during in-vitro study. The extract of BR revealed significant inhibition in differentiated cell as compared to non-differentiated cell in 3T3-L1 cell line [31]. Improvement in lipid profile reduces the possibilities of diabetes induced obesity and cardiovascular diseases [32]. BR extract normalized the amount of triglycerides (TG) and total cholesterol (TC) in STZ-induced diabetic rats and may be effective for the treatment of cardiovascular disease like coronary artery disease, atherosclerosis etc. Triglycerides (TG) are prepared from carbohydrates as a major energy source or derived from fats, by taking food [33]. Calories present in food is not absorbed immediately by tissues; it is converted into TG and transported to fat cells for storage. Release of triglycerides from fat tissues is regulated by hormones to meet the body's needs for energy between meals. Excess triglycerides in plasma are called hypertriglyceridemia. Elevation in triglyceride level may be a consequence of another disease like untreated diabetes mellitus. STZinduced diabetes and adipocyte differentiation assay have been used as a model to evaluate the effect of test products on lipid/fat metabolism [34, 35]. To develop the antidiabetic drugs and antiadipogenic drugs the lipid centric approach has been widely used.

\section{Conclusion}

It is revealed from the present study that BR extract possess antidiabetic activity due to decreasing blood glucose level of STZ-induced diabetic rats. Furthemore, BR extract also exhibits lowering effect on lipid level and adipose tissue. Due to this property the extract showed significant antiadipogenic and hypolipidemic effect. Pharmacologically, the extract improved the lipid profile by decreasing the levels of serum triglycerides, total cholesterol, LDL and increasing HDL cholesterol.

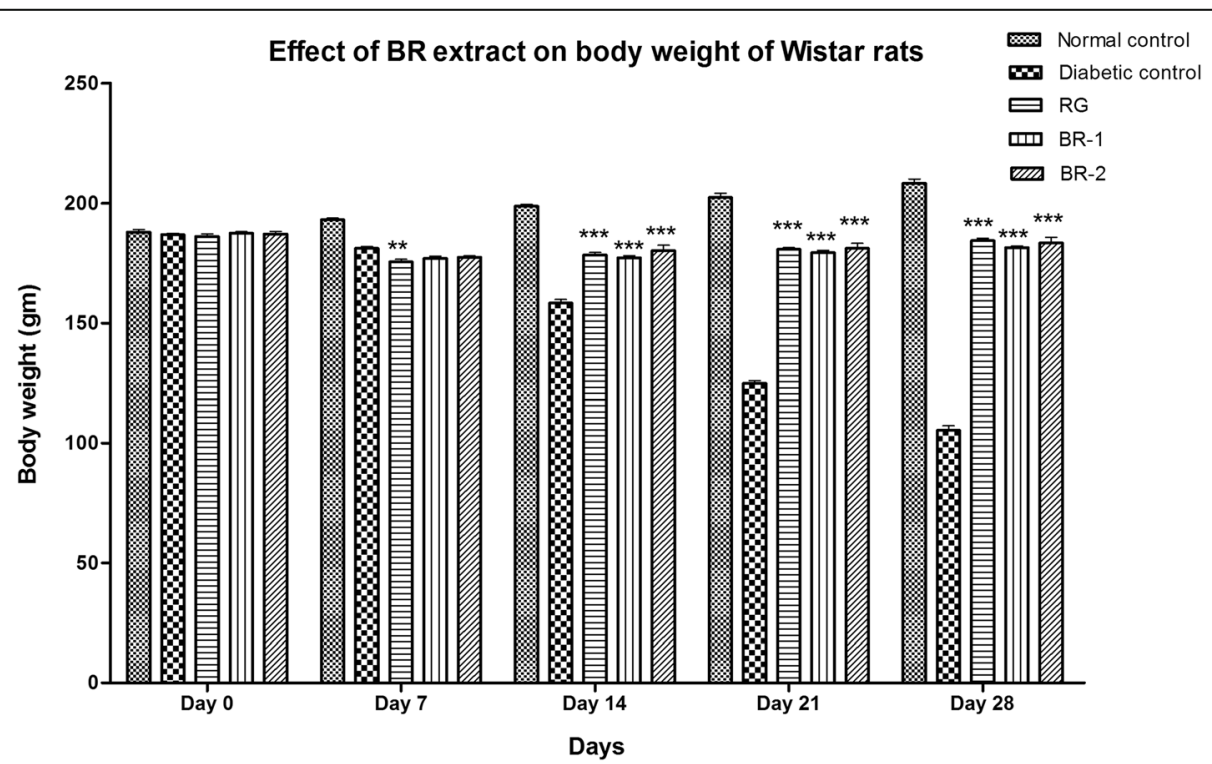

Fig. 4 Effect of BR extract on body weight of diabetic rats. $N C=$ Normal control, $D C=$ Diabetic control, $R G=$ Reference group (glibenclamide), $B R-1=B R$ extract in dose of $250 \mathrm{mg} / \mathrm{kg}, \mathrm{BR}-2=\mathrm{BR}$ extract in dose of $500 \mathrm{mg} / \mathrm{kg}$. Values are expressed in mean \pm S.E.M. Where $n=6,{ }^{*} p<0.05$, ${ }^{* *} p<0.01,{ }^{* * *} p<0.001$; compared with diabetic control group 
Conclusively, these effects of BR may be useful for the development of potent herbal medicine for diabetes. The relevance of anti-obesity mechanism of BR extractmay be more appropriate. Further studies to isolate, identify and characterize the active principle(s) are in progress.

\section{Abbreviations}

BR: Bauhinia racemosa; BR-1: test group-1; BR-2: test group-2; DC: diabetic control; DE: dark extract; DMEM: Dulbecco's modified Eagle's medium; DMSO: Dexamethasone, Dimethyl sulfoxide; EDTA: Ethylenediamine tetraacetic acid; FBS: Fetal bovine serum; HDL: High density lipoprotein; IDDM: Insulin dependent diabetes mellitus; LDL: Low density lipoprotein; LE: Light extract; NC: Normal control; NIDDM: Non-insulin dependent diabetes mellitus; RG: Reference group; RPMI: Roswell Park Memorial Institute medium; TC: Total cholesterol; TG: Triglycerides

\section{Acknowledgement}

Authors are thankful to Dr. Zabeer Ahmed, Principal Scientist, Department of Pharmacology, Indian Institute of Integrative Medicine (IIIM), Jammu for their guidance and providing space in laboratory to carry out work and also showing gratitude towards Indian Institute of Integrative Medicine (IIIM), Jammu for their assistance to provide all the facilities required during the study.

\section{Authors' contributions}

VK carried out the pharmacology evaluation, participated in the dosing, animal care, feeding etc. KR carried out the in-vitro antiadipogenic studies. PJ participated in the design of the study, performed the statistical analysis and drafted manuscript. ZA conceived of the study and participated in its design and coordination. All authors read and approved the final manuscript.

\section{Competing interests}

The authors declare that they have no competing interests.

\section{Author details}

${ }^{1}$ Department of Pharmacology, School of Pharmacy, Babu Banarasi Das University, Lucknow, (U.P.) 226001, India. ²Department of Pharmacology, University teaching department, Sarguja University, Amibakpur, (C.G.) 497001, India. ${ }^{3}$ Department of Pharmacology, Institute of Pharmaceutical Sciences, Guru Ghasidas Vishwavidyalaya Koni, Bilaspur, (C.G.) 495009, India. ${ }^{4}$ Department of Pharmacology, Indian Institute of Integrative Medicine, Jammu, (J\&K) 18000, India.

Received: 10 August 2016 Accepted: 10 February 2017 Published online: 08 March 2017

\section{References}

1. American Diabetes Association. Diagnosis and classification of diabetes mellitus. Diabetes Care. 2009;32(1):S62-7.

2. American Diabetes Association. Diagnosis and Classification of Diabetes Mellitus. Diabetes Care. 2005; 28: (1)

3. Christopher L., Cook J.T., William E.W., Endocrinologic Disorders. Text book of Pharmacotherapy Principles and Practice, 7thed. Mc Graw Hill Companies, US. 40:643-685.

4. Yuankai S, Hu FB. The global implications of diabetes and cancer. Lancet. 2014;383(9933):1947-8.

5. Franz MJ. The dilemma of weight loss in diabetes. Diabetes Spectr. 2007; 20(3):133-6.

6. Hajer GR, Haeften TW, Visseren FL. Adipose tissue dysfunction in obesity diabetes, and vascular diseases. Eur Heart J. 2008;29:2959-71.

7. Mishra A, Nautiyal S, Nautiyal DP. Growth characteristics of some indigenous fuelwood and fodder tree species of sub-tropical Garhwal Himalayas. Indian Forester. 2009;135(3):373-9.

8. Kirtikar KR, Basu BD. In: Mhaskar KS, Cains JF, editors. Indian Medicinal Plants. Delhi: Sri Satguru Publications; 2001

9. Dahikar SB, Bhutada SA, Tambekar DH, Vibhute SK, Kasture SB. In-vitro antibacterial efficacy of solvent extracts of leaves of bauhinia racemosa Lam. (caesalpiniacea) against enteric bacterial pathogens. Int J Pharm Sci Drug Res. 2011;3(1):32-4.

10. Gupta M, Mazumder UK, Kumar TS, Gomathi T, Kumar RS. Antioxident and hepatoprotective effect of bauhinia racemosa against paracetamol and carbon tetra chloride induced liver damage in rats. Iran J Pharmacol Ther. 2004;3:12-20.

11. Prusty KB, Rao JV, Subudhi SK, Reddy PA. Anti Hyperglycemic Activity of Extracts of Leaves of Bauhinia racemosa Lamk (Family-Caesalpineaceae) on Normal and Alloxan-Induced Diabetic Rats. Int J Pharm Res Allied Sci. 2012; 1(4):94-9.

12. Sasidharan N. Biodiversity documentation for Kerala Part 6. Flowering Plants. Peechi: Kerala Forest Research Institute; 2004.

13. Kumar AS, Venkatarathanamma V, Suneeta K, Kumari BS. Comparative in vitro screening of a-amylase and a-glucosidase enzyme Inhibitory studies in leaves of annona species. J Pharmacy Res. 2011:4:4431-4.

14. Davey SM, Atlee WC, Ashok SRS, Bharathi, Farookanti M. Anxiety effect of methanolic extract of bauhinia racemosa stem bark in mice. Int J Pharm Bio Sci. 2011;2:217-24.

15. Yadav RD, Jain SK, Alok S, Mahor A, Bharti JP, Jaiswal M. Herbal plants used in the treatment of urolithiasis: a review. IJPSR. 2011;2(6):1412-20.

16. Kumar V, Jain P, Rathore K, Ahmed Z. Biological Evaluation of Pupalia lappacea for Antidiabetic, Antiadipogenic, and Hypolipidemic Activity both in Vitro and in Vivo. Scientifica. 2016; 9.

17. WHO (World Health Organization). WHO guidelines for assessing quality of herbal medicines with reference to contaminants and residues. 2007.

18. Rathore K, Singh VK, Jain P, Rao SP, Ahmed Z, Singh VD. In-vitro and in-vivo antiadipogenic, hypolipidemic, andantidiabetic activity of Diospyros melanoxylon (Roxb). J Ethnopharmacol. 2014;155:1171-6.

19. Choy L, Skillington J, Derynck R. Roles of autocrine TGF-ß receptor and smad signaling in adipocyte differentiation. J Cell Biol. 2000;149:667-82.

20. Singh RR, et al. Anti adipogenic, anti-diabetic and antioxidant potential of tinospora cordifolia. Inventi rapid. Ethno pharmacol. 2013;2:1-11.

21. Kant HT, Ahmed Z, Pooja SKC, Samanta CK. Antihyperglycemic activity of petroleum ether extract \& ethyl acetate extract of sarcococca saligna. Int J Curr Pharm Res. 2011:3:26-9.

22. Kedar $\mathrm{P}$, Chakrabarti $\mathrm{CH}$. Effects of bittergourd (momordica charantia) seed and glibenclamide in streptozotocin induced diabetes mellitus. Indian J Exp Biol. 1982;20:232-5.

23. Rydgren T, Bengtsson D, Sandler S. Complete protection against interlukin-1 beta-induced functional suppression and cytokine-mediated cytotoxicity in rat pancreatic islets in vitro using an interlukin-1 cytokine trap. Diabetes. 2006;55:1407-12.

24. Allain CC, Poon LC, Chan CS, Richmond W, Fu PC. Enzymatic determination of total serum cholesterol. Clin Chem. 1974:20:470-5.

25. Gray AM, Flatt RP. Insulin-secreting activity of the traditional antidiabetic plant viscum album. J Endocrinol. 1999:160:409-14.

26. Chishti Z, et al. Antihyperglycemic and antidyslipidemic activity of aqueous extract of dioscorea bulbiferan tubers. Diabetol Croat. 2009:38:63-72.

27. Gray AM, Flatt PR. Pancreatic and extra-pancreatic effects of the traditional antidiabetic plant, medicago sativa (Lucerne). Br J Nutr. 1997:78:325-34.

28. Gray AM, Flatt PR. An antihyperglycemic action of eucalyptus globules (eucalyptus) is associated with pancreatic and extra-pancreatic effects in mice. J Nutr. 1998;128:2319-23.

29. Gray AM, Abdel W, Flatt P. The traditional plant treatment, sambucus nigra (elder), exhibits insulin-like and insulin-releasing actions in vitro. Br J Nutr. 2000;130:15-20

30. Bierman EL, Amaral JAP, Belknap BH. Hyperlipidemia and diabetes mellitus. Diabetes. 1966;15:675-9.

31. Choi BH, Kim YH, Byun JM. The inhibition of inflammatory molecule expression on 3 T3-L1 adipocytes by berberine is not mediated by leptin signalling. Nutr Res Pract. 2009;3:84-8.

32. Castelli WP, et al. HDL cholesterol and other lipids in coronary heart disease. Coop lipoprotein phenotyping study. 1977:55:767-72.

33. Buccolo G, David H. Quantitative determination of serum triglyceride by the use of enzymes. Clin Chem. 1973:19:76-480.

34. Gregoire FM, Smas CM, Sook SH. Understanding adipose differentiation. Physiol Rev. 1998;78(3):783-809.

35. Jaiswal $D$, et al. Effect of moringa oleifera Lam. Leaves aqueous extract therapy on hyperglycemic rats. J Ethnopharmacol. 2009;123:392-6. 